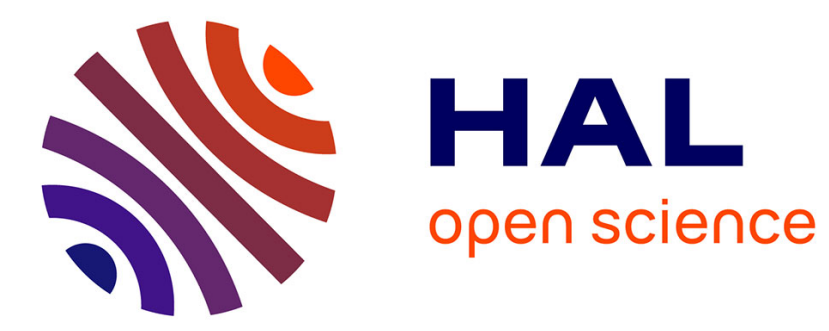

\title{
Multiple aims in the development of a major reform of the national curriculum for science in England
}

\author{
Jim Ryder, Indira Banner
}

\section{To cite this version:}

Jim Ryder, Indira Banner. Multiple aims in the development of a major reform of the national curriculum for science in England. International Journal of Science Education, 2010, pp.1. 10.1080/09500693.2010.485282 . hal-00608919

\section{HAL Id: hal-00608919 \\ https://hal.science/hal-00608919}

Submitted on 16 Jul 2011

HAL is a multi-disciplinary open access archive for the deposit and dissemination of scientific research documents, whether they are published or not. The documents may come from teaching and research institutions in France or abroad, or from public or private research centers.
L'archive ouverte pluridisciplinaire HAL, est destinée au dépôt et à la diffusion de documents scientifiques de niveau recherche, publiés ou non, émanant des établissements d'enseignement et de recherche français ou étrangers, des laboratoires publics ou privés. 


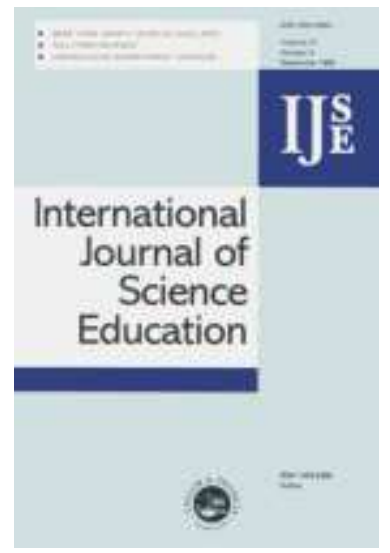

Multiple aims in the development of a major reform of the national curriculum for science in England

\begin{tabular}{|r|l|}
\hline Journal: & International Journal of Science Education \\
\hline Manuscript ID: & TSED-2009-0389.R3 \\
\hline Manuscript Type: & Research Paper \\
\hline Keywords: & $\begin{array}{l}\text { curriculum, policy development, scientific literacy, secondary } \\
\text { school, science education }\end{array}$ \\
\hline Keywords (user): & \\
\hline \multicolumn{2}{|c}{} \\
\hline
\end{tabular}

\section{S) ScholaroNE}




\title{
Multiple aims in the development of a major reform of the national curriculum for science in England
}

\begin{abstract}
In the context of a major reform of the school science curriculum for 14-16 year olds in England we examine the aims ascribed to the reform, the stakeholders involved and the roles of differing values and authority in its development. This reform includes an emphasis on socioscientific issues and the nature of science; curriculum trends of international relevance. Our analysis identifies largely 'instrumental' aims, with little emphasis on 'intrinsic' aims and associated values. We identify five broad categories of stakeholders focusing on different aims with, for example, a social, individual, political or economic emphasis. We suggest that curriculum development projects reflecting largely social and individual aims were appropriated by other stakeholders to serve political and economic aims. We argue that a curriculum reform body representing all stakeholder interests is needed to ensure that multiple aims are considered throughout the curriculum reform process. Within such a body the differentiated character of the science teaching community would need to be represented.
\end{abstract}


Multiple aims in the development of curriculum reform

\section{Introduction}

Previous studies have identified the school science curriculum as 'contested terrain' (Fensham, 2009) with many distinct aims ascribed to it (Aikenhead, 2006; Black \& Atkin, 1996; Reiss, 2007). For example, supporting the development of 'scientific literacy' for all students is an increasingly prominent aim for school science education (DeBoer, 2000; Laugksch, 2000; Roberts, 2007). However, school science education is also the starting point for further science study and potentially a career in science, technology or engineering. In contrast to scientific literacy this is an aim relevant to a minority of students in schools. Such multiple aims can create tensions (Roberts, 1988). For example, should the school science curriculum emphasise the traditional academic content of the separate physical, chemical and biological sciences (providing a solid foundation for further science study) or focus more on how science features alongside ethical, social and political issues within contexts such as air pollution or global warming (principally serving the aims of scientific literacy)? This paper considers how such multiple aims, and associated tensions, featured in the development of a major reform of the school science curriculum for 14-16 year olds in England.

Despite concerns over the failures of many previous science curriculum reforms (Blades, 1997; Eijkelhof \& Kapteijn, 2000) there has been relatively little research into the development of curriculum policy and its interaction with practice (Aikenhead, 2006; Fensham, 2009). Drawing upon Kogan's view of policy as the authoritative allocation of values (Kogan, 1975) Fensham (2009) identifies two sets of important, but neglected, research questions focusing on the role of values and 
authority respectively in education policy (see also Corrigan, Dillon, \& Gunstone, 2007). This paper contributes to this research agenda through an analysis of the development of a major reform of the school science curriculum in England. We consider the role of values by examining the aims ascribed to this curriculum reform and the stakeholders promoting these aims. We address the role of authority by identifying those stakeholders who were successful in shaping the reform, and also those stakeholders who were more peripheral. Significantly, we identify a key moment in the development of the reforms when the authority of one group of stakeholders was particularly decisive. Finally, we consider the implications of this analysis of curriculum reform within England for curriculum development initiatives internationally.

Several features of our chosen curriculum reform make it an appropriate context in which to explore these issues. The reform provides a range of science courses aimed at enabling teachers to match the perceived needs of their students (QCA, 2005b, p. 9). This includes an enhanced presence for courses focusing on science within employment settings ('applied science' courses). The reform also emphasises the teaching of socioscientific issues and the nature of science. This is a curriculum emphasis reflected in current science curriculum reform initiatives in many countries (Black \& Atkin, 1996; van den Akker, 1998), for example those emphasising science inquiry (Rudolph, 2005) and science-society-technology (STS) teaching (Solomon, 1993). Thus, multiple aims feature strongly across these different courses. Furthermore, it is a statutory reform: all publically funded schools in England are required to respond to it. Thus, the reform impacts on virtually all stakeholders in the 
school science curriculum, providing a rich context in which tensions between distinct aims for school science are likely to surface.

\section{A conceptual framework for examining curriculum policy development}

The focus of this paper can be expressed in terms of a policy process 'cycle' (Bowe, Ball, \& Gold, 1992). The representation shown in Figure 1 moves away from a linear view of policy generation followed by policy implementation, reflecting trends in the analysis of the policy-practice relationship in a range of policy contexts (Elmore \& Sykes, 1992; Hill \& Hupe, 2002).

\section{[Insert Figure 1 about here]}

Figure 1 emphasises the complexity of the policy process, the different contexts in which policy is developed, and the ways in which these contexts interact over time. Crucially, in this view policy can only achieve meaning through practice. The use of the term 'policy cycle' reflects this dynamic character of the policy process. Three interacting policy contexts are identified. Policy is initiated and constructed within the 'context of influence'. This includes both private arenas of influence (e.g. social networks in and around government) and public arenas of influence (e.g. curriculum committees). Secondly, in the 'context of policy text production' policy is 'represented' through policy texts: statutory policy statements, official commentaries and speeches. The term 'represented' is important here: the language of these policy texts tends to be 'articulated in the language of general public good' (Bowe et al., 1992, p. 20) whilst representing hidden values and interests generated within contexts of influence. Reflecting the interactive, cyclical nature of the policy process such 
Our analysis focuses largely on the 'context of policy text production'. We examine official government curriculum documents and published reactions and commentaries from a range of non-governmental stakeholders. Such texts provide the 'public face' of curriculum policy through which policy aims are communicated to stakeholders. Whilst we do not claim to have examined all relevant documents, we did review all documents in the public domain that, in our judgement, had a significant impact on the formation of these reforms. In addition we provide some insights into the "context of influence' through consideration of the activities of government-initiated curriculum projects and curriculum development projects funded by charitable organisations. For example, we are interested in who was involved in such activities. However, we did not attempt systematically to examine sources such as minutes of government meetings or, through formal interview, the reflections of those involved. Our experience has been that such sources are difficult to access and interpret. Finally, the context of practice features in our analysis through consideration of the outcomes and influence of several evaluation studies of piloted curriculum initiatives.

\section{The development of the 2006 reform}


We examine three sequences of activities that played a major role in shaping the reform: the Beyond 2000 seminar series; a government-funded curriculum development project; and the design and evaluation of the Twenty First Century Science courses. We also refer to broader policy initiatives in England with implications for the school science curriculum. Table 1 gives an overview of the activities referred to.

[Insert Table 1 about here]

\section{Beyond 2000 seminar series}

From January 1997 to April 1998 a series of six seminars led by university-based science education researchers was held in the UK. The aim of the Beyond 2000 seminar series was to 'consider and review the form of science education required to prepare young people for life in our society in the next century' (Millar \& Osborne, 1998, p. 1). Three distinct aims for school science education appeared in the early part of the Beyond 2000 report: enhancing student interest by promoting a sense of wonder and curiosity about the achievements of science; supporting the development of scientific literacy; and preparation for more advanced science study. In the report scientific literacy was characterised as follows:

School science education should aim to produce a populace who are comfortable, competent and confident with scientific and technical matters and artefacts. The science curriculum should provide sufficient scientific knowledge and understanding to enable students to read simple newspaper articles about science, and to follow TV programmes on new 
Of the three aims identified above that of achieving scientific literacy was the most prominent in the main body of the report. The report recommended the development of a core science course for all students focusing on scientific literacy with a flexible suite of additional courses to match the needs of particular students. The report also outlined a set of 'ideas-about-science' to be taught alongside more traditional science content. These 'ideas-about-science' included aspects of the nature of science and socioscientific issues; these themes would reappear in the 2006 reform.

The Beyond 2000 project was funded by the Nuffield Foundation a charitable organisation with a long history of supporting influential curriculum development in the sciences (The Nuffield Foundation). The majority of those involved in the seminars were university academics with a professional interest in school science education (Millar \& Osborne, 1998, p. 32). The principal motivation for the project, as expressed by the authors in the opening paragraph of the report, was to address their growing concern about the lack of relevance of the current science curriculum to the needs and interests of all young people. Whilst professional scientists had some representation at the seminars their role appears not be have been a prominent one. Despite being neither initiated or funded by the government the Beyond 2000 report has played a significant role in the development of the reform of the National Curriculum for Science in England; an influence acknowledged explicitly by curriculum officials in the government (QCA, 2006). Thus the Beyond 2000 project is 
Multiple aims in the development of curriculum reform

an example of a non-governmental, non-legitimised interest group (Kogan, 1975) exerting authority in the development of national curriculum reform, illustrating the multiple stakeholders working within the 'context of influence' represented in Figure 1.

Qualifications and Curriculum Authority curriculum project

In 2000 the Qualifications and Curriculum Authority (QCA) initiated a curriculum development project 'Keeping School Science in Step with the Changing World of the $21^{\text {st }}$ Century'. The QCA was the government body responsible for the National Curriculum in England at that time. The project was the government's response to the Beyond 2000 report (QCA, 2006). Three separate studies were commissioned. Study 1 developed a definition of scientific literacy that might underpin the school science curriculum for 14-16 year olds. School science teachers and a broad range of additional stakeholders were then asked for their responses to this definition (Leach, 2002). Study 2 evaluated methods for assessing student understanding of the nature of science and socioscientific issues (Osborne \& Ratcliffe, 2002). Study 3 developed curriculum models for science that might address the aims of scientific literacy (Millar, 2006).

Stakeholders within the QCA stated that this curriculum development project aimed to: address poor student motivation for science education; support students' future engagement with science issues outside of school; and provide students with a foundation for further study in the sciences (Hollins, 2001, p. 22). The inclusion of Study 2, which examined the assessment of the nature of science and socioscientific issues, reflects recognition within the QCA that assessment in schools is a significant 
There was a striking level of continuity of stakeholder involvement in the Beyond 2000 and QCA curriculum development projects. The key authors of the QCA reports were university-based science education researchers many of whom had also contributed to the Beyond 2000 seminar series. However, studies also involved additional stakeholders, particularly school science teachers. In engaging with teacher stakeholders Study 1 in particular identified many 'critical voices' in relation to the meaning and feasibility of the goals of scientific literacy. For example, there was little agreement amongst those consulted about the content of any future curriculum that might support students as 'consumers and users' of science. Study 1 also found that 'there was some doubt as to whether pupils could be prepared to engage with expert science through the science curriculum' and no consensus on the impact of such teaching on student motivation (Leach, 2002, p. 49). However, as shown below these concerns appear to have been given limited attention within subsequent developments.

Twenty First Century Science 
In 2002 the development of a new suite of science courses began (21st Century Science Project Team, 2003). The Twenty First Century Science (21CS) project set out to address two aims for science education: to develop the scientific literacy of all students to support their engagement with science-related issues in later life, and to provide the foundations for more advanced courses in science (Millar, 2006). The project aimed to achieve this through a flexible suite of courses for 14-16 year olds to be taken in the last two years of compulsory schooling (OCR, 2009; University of York/Nuffield Foundation, 2009). The 21CS suite would be available as an option for schools. All students following 21CS would complete a 'core' 21CS course. This course provided 'a broad, qualitative grasp of the major science explanations' (Millar, 2006, p. 1507) and also included insights into the nature of science and its relation to social and ethical issues. Within the 21CS curriculum model the majority of students would also opt for one of two additional science courses offering either traditional science content or a focus on the applications of science within everyday and workrelated contexts.

The 21CS curriculum framework had much in common with the outcomes of Study 3 (curriculum models) of the QCA curriculum development project referred to earlier. Indeed, Robin Millar, a Professor of Science Education based at the University of York and a lead member of the 21CS development team, had been involved centrally in Beyond 2000 and Study 3 of the QCA curriculum project. Taken together these activities comprised a long term, coherent sequence of projects focused on the development of a curriculum emphasising scientific literacy, alongside other goals, and involving a common core of university-based science education researchers. 
In addition to this development work the QCA commissioned a pilot of $21 \mathrm{CS}$ in 78 volunteer schools and colleges across England from September 2003. Two early evaluation studies of this pilot were conducted by the QCA (QCA, 2005a). The broadly positive indications from these studies were used by the government to justify the introduction of related reforms on a national scale (House of Lords Science and Technology Select Committee, 2007, p. 5). A more substantial evaluation, involving three linked studies, was commissioned by the charitable organisations funding the 21CS project in 2004 (Burden, Campbell, Hunt, \& Millar, 2007). However, final reports from the second set of evaluations were completed in 2006; too late to influence the formation of the 2006 reform.

\section{Introduction of the science curriculum reform at national level}

In February 2004 the government published the revised 'programme of study' for science: the statutory science curriculum content to be followed within all publically funded schools in England from September 2006 (DfES/QCA, 2004). Featuring 
prominently on the inside front cover of the programme of study was a statement of aims for the new national curriculum:

\author{
The purpose of the changes is to increase the flexibility of qualifications \\ [for 14-16 year olds] to provide for the wide range of student interests \\ and aptitudes so that more students will be encouraged to study more \\ science (DfES/QCA, 2004).
}

The focus of this statement of aims was on encouraging greater post-compulsory participation in science education; there is no explicit reference here to achieving the aims of scientific literacy. This was in contrast to the focus on scientific literacy within the Beyond 2000 seminar series, the reports of the QCA curriculum projects and the 21CS project. The programme of study included a later section entitled 'the importance of science'. Here, additional aims for school science education were suggested: '[science] does provide us with the most robust information about the way the universe works that has so far become available to us'; '[science] trains the mind in a way that industry prizes'; 'science stimulates and excites pupils' curiosity'; '[pupils] learn to question and discuss science-based issues that may affect their own lives' (DfES/QCA, 2004, pp. 14-15). However, whilst the programme of study explicitly recognised a range of aims for science education, the aim of enhancing postcompulsory participation in science education appeared most prominently.

This emphasis on enhancing post-compulsory participation within the official government statement of curriculum was reflected in similar priorities within other government policy initiatives at that time. Two examples are given here. In 2004 the 
Another policy strand in England at this time was the development of a variety of progression routes through 14-19 education broadly, including vocational routes, in order to provide a curriculum that is motivating for all students (Tomlinson, 2004). Enhancing educational opportunity was identified in a government policy paper as 'vital for social justice - giving us the chance to break forever the historic link between social background, educational achievement and life chances that have dogged us as a nation' (DfES, 2005, p. 3). However, in the context of the science curriculum for 14-16 year olds, the emphasis returned to the need to improve science attainment and increase post-compulsory participation in science courses in order to sustain the supply of scientists and engineers (DfES, 2005, p. 39).

The revised statutory curriculum framework, whilst different from that of the 21CS pilot, shared several characteristics with it (e.g. a 'core' science course for all students focusing on scientific literacy with the flexibility of additional options; an emphasis on aspects of the nature of science and socioscientific issues). For many stakeholders the decision to adopt this curriculum framework at a national level ahead of the 
completion of evaluations of the 21CS pilot was premature (House of Lords Science $\&$ Technology Select Committee, 2006, p. 22). For example, the final chapter of the Beyond 2000 report recommended that curriculum innovations should be piloted and evaluated in a representative range of schools and the outcomes used to inform subsequent changes at the national level (Millar \& Osborne, 1998, p. 30). The motivations of the government officials involved in the decision to implement the revised statutory curriculum framework were not recorded, at least within the publically accessible documents examined here. It is possible that they felt that a science course (21CS) whose initial evaluation indicated enhanced interest amongst teachers and students might result in greater participation in post-compulsory science courses. The emphasis on scientific literacy also corresponded with the development by QCA of a whole school curriculum policy that emphasised citizenship and public engagement across the school curriculum (QCA, 2007). Irrespective of their motivations stakeholders within government made this critical decision from a position of authority over stakeholders such as those involved in the Beyond 2000 and 21CS development activities and science teachers working in schools.

\section{Discussion}

Table 2 summarises the multiple aims identified in the case study presented above.

[Insert Table 2 about here]

The first column summarises the key changes associated with the 2006 reforms. The next two columns distinguish between 'immediate aims' within compulsory 14-16 science education and 'longer term aims' related to post-compulsory education and 
beyond. We can use Table 2 to identify the links different stakeholders make between specific changes to the curriculum and immediate and/or future aims. Any such links can be considered as 'routes' through Table 2. These 'routes' are also indicative of the values of different stakeholders (Kogan, 1975). For example, the Beyond 2000 report advocated teaching about the nature of science and socioscientific issues in order to increase student motivation and interest in their science education with the longer term goal of supporting them in engaging effectively with science-related issues as citizens. Such links form a 'route' across the top row of Table 2 and emphasise values associated with self-determination and equity. There was little emphasis within Beyond 2000 on supporting post-compulsory participation in science education. By contrast, many government documents (e.g. the Science and Innovation Investment Framework) emphasised the need to improve student interest and attainment in science in order to increase the pool of students participating in post-compulsory science education thereby ensuring an adequate supply of future scientists and engineers. The emphasis here is on values of progress and institutional maintenance. Other government documents refered to increased flexibility of provision leading to improvements in student attainment and post-compulsory participation (DfES, 2005). These developments were seen as serving the aims of enhancing general employability within a highly developed science/technology workforce and promoting values of social mobility and inclusion. Such links form 'routes' through the middle and lower sections of Table 2 .

Overall, the activities examined in this paper tended to take an instrumental view of the aims of science education. For example, they focused on specific future functions that science education might serve (e.g. increasing post-compulsory participation in 
Multiple aims in the development of curriculum reform

formal science education) or specific capacities that students might develop (e.g. engaging with science issues in the popular news media). The activities tended not to reflect a more liberal or intrinsic view of education: introducing students to the power and wonder of the science worldview with educational aims 'grounded in intellectual and personal outcomes for pupils' (Donnelly, 2005, p. 294). These educational aims reflect the nature of the subject itself; they are intrinsic to the subject and independent of the uses to which any learning might be put. These purely educational values did not have a strong presence within the documents examined here.

The range of distinctive aims associated with the 2006 reform gives the potential for significant tensions. For example, the 2006 reform provides schools with a wider choice of science courses than was available previously. Stakeholders within the QCA have suggested that this flexibility should enhance student motivation for science education by enabling them to follow a science course that matches their needs and interests (QCA, 2005b). However, in practice these course 'choices' follow largely from student attainment. For example, science courses focusing on science within employment settings ('applied science' courses) tend to be the preserve of mid-tolower attaining students, at least within England (Bell \& Donnelly, 2007). Such stratification of students by attainment within compulsory science education is likely to work against the achievement of broader social mobility and inclusion in later life (Ball, 2008; Gorard \& See, 2009); an explicit aim within other government documents associated with the 2006 reform (DfES, 2005). Our analysis provides no evidence that such a critical tension was recognised or considered by the stakeholders involved.

Curriculum demands and associated stakeholders 
[Insert Figure 2 about here]

Here we use the representation in Figure 2 to consider the different roles of five distinct categories of stakeholder who feature in our analysis: university-based science education researchers; professional scientists; representatives of charitable organisations (e.g. the Nuffield Foundation); school teachers; and government policy makers. We also examine different positions of authority across these stakeholders, and how such authority was manifested.

In Fensham's view political, economic and subject maintenance demands usually carry the most weight in determining science curriculum and assessment, with individual, social and cultural factors 'often given prominence in the preambles to a curriculum as some sort of consolation prize' (Fensham, 2009, p. 5). Certainly the economic demand to increase the supply of scientists had a strong presence in many of the documents examined here. Political demands were also prominent, e.g. enhancing student attainment, as measured by national or international assessments, and improving social inclusion and gender equity. In the context of the reforms in England the principal stakeholders associated with these demands were government policy makers.

Other demands also had a strong presence. For example, publications associated with the Beyond 2000 and 21CS projects addressed both social demands (e.g. enhancing 
democratic engagement with science-related social and ethical issues such as genetic engineering) and individual demands (e.g. enabling individuals to deploy science understandings in making personal decisions about diet, nutrition and exercise). The associated environmental demand was also present; issues such as climate change and sustainability feature strongly within $21 \mathrm{CS}$ resources. Far from being a 'consolation prize' individual, social and environmental demands were the principal focus of at least some of the curriculum development activities examined here. In terms of the stakeholders involved, university-based science education researchers and representatives of charitable organisations were the main stakeholders advocating these demands.

In the context of the 2006 curriculum reform in England, the demands of 'subject maintenance' are less visible. Traditionally the stakeholders highlighting the need to maintain the profile and identity of the separate science subjects within the school curriculum have been professional scientists, acting as 'guardians of the disciplines' (Gaskell, 2003, p. 140). However, professional scientists did not feature as central players in the activities described above. This reflects what has been identified as a shift of ownership of the science curriculum since the latter half of the 20th century away from professional scientists (Black \& Atkin, 1996, p. 60). Our analysis shows that the most prominent subject-related stakeholders within the curriculum projects influencing the 2006 reform were university-based science education researchers. These academics are likely to have stronger links with university education departments than with university science departments. A similar outcome has been identified in relation to the redesign of the chemistry curriculum towards the aims of scientific literacy in China (Wei \& Thomas, 2005). 
Multiple aims in the development of curriculum reform

The voices of science teachers (and through them those of their students) were not prominent in the development of the 2006 reforms in England. Referring to the cyclical model of the policy process introduced earlier, recreating curriculum policy within schools involves a continuous interaction with curriculum policy texts within contexts of practice; science teachers are 'curriculum creators' rather than 'curriculum deliverers' (Pring et al., 2009). This process takes many years; a point highlighted by Kahle in her review of 60 years of science education reform in the US (Kahle, 2007). Teacher stakeholders were involved in the piloting of 21CS. However, the 2006 reforms were finalised ahead of the publication of the more extended evaluation of this pilot. Furthermore, teacher responses critical of the meaning and feasibility of scientific literacy within the science classroom identified within Study 1 of the QCA curriculum project appear not to have been engaged with in subsequent developments. There was also insufficient attention given to the differentiated character of the science teaching community (Donnelly \& Jenkins, 2001). Science teachers differ in their skills, aspirations and identities, the places in which they work and the students that they work with (Banner, Ryder, \& Donnelly, 2009; Witz \& Lee, 2009). The teachers involved in the piloting of 21CS (or at least their heads of department) had volunteered to be involved in this curriculum innovation. However, the voices of other, perhaps more traditional, science teachers did not feature strongly.

Our case study has shown the differential authority positions held by each of these groups of stakeholders. The Beyond 2000 project exerted authority by initiating a sequence of influential curriculum development activities. The principal stakeholders in Beyond 2000 were university-based science education researchers and 
Multiple aims in the development of curriculum reform

representatives of charitable organisations. However, the locus of authority shifted towards government stakeholders as these development activities progressed. Ultimately, the authority of government stakeholders resulted in the premature installation of a national statutory curriculum framework sharing many features of the $21 \mathrm{CS}$ courses being piloted at that time. The implications of this policy decision within schools is the focus of ongoing work (Banner et al., 2009). Finally, we have shown that professional scientists, school science teachers and their students had little authority within the development of this reform.

\section{Implications}

Here we consider messages that might be drawn from our analysis for the development of science curriculum reform policies internationally. We first discuss the need for a significant school-based pilot phase ahead of any national or regional rollout of curriculum reform. From the theoretical perspective represented by the policy process cycle in Figure 1 curriculum reform necessarily involves engaging with the context of practice. The purpose of a pilot phase is therefore to engage with practice in a planned and controlled fashion, with evaluation tools built in, such that any lessons learnt can be used to further develop the reform ahead of any broader roll-out. There are also pragmatic reasons for a significant pilot of curriculum reform. Highly motivated 'early adopter' teachers who volunteer to be involved in a curriculum pilot will develop pedagogic resources associated with the innovative elements of any course, e.g. teaching activities and assessment instruments in the context of socioscientific issues. One outcome of a pilot would be that this essential practitioner expertise will be available to support 'later adopters' and even 'reluctant adopters' following any broader roll-out. Finally, any pilot phase would also need to represent 
the differentiated character of the teaching community; to involve both those teachers looking to change their practice, but also (in the case of a statutory reform) those teachers who are broadly comfortable with existing curricula.

In addition to teachers and their students other stakeholders also need to have a voice in the development of curriculum reform. Curriculum reform is a necessary compromise between competing stakeholder demands (Roberts, 1988). Not paying sufficient attention to such multiple demands lies behind the failure of many previous reforms of science education with a focus on scientific literacy (Blades, 1997; Eijkelhof \& Kapteijn, 2000). For example, earlier we identified a shift of ownership of the science curriculum away from professional scientists. However, as reform is enacted their role is likely to grow. For example, professional scientists working in universities are involved in selecting those students who are chosen to follow sciencerelated courses within universities. Furthermore, returning to the role of teachers in curriculum reform, these key stakeholders need to be involved centrally in all of the policy contexts represented in Figure 1, and not simply at the 'pilot' or ‘implementation' phase (Kirk \& MacDonald, 2001).

Our analysis lends support to calls for a body representing all stakeholders to have responsibility for national or regional curriculum reform (House of Lords Science \& Technology Select Committee, 2007, p. 17; The Royal Society, 2008). Within such a body all five categories of stakeholder identified in our analysis would have an active and ongoing role within each of the policy contexts represented in Figure 1. Additional stakeholders would also need to be involved such as representatives of professional organisations for scientists, teachers, parents, students, school inspectors and 
Multiple aims in the development of curriculum reform

examining bodies. Such a body would draw upon an understanding of the successes and failures of previous curriculum reform initiatives. It would also be responsible for ensuring that any reform is preceded by a significant pilot phase within a representative sample of schools. An allocation of funds to support such piloting and associated evaluation would be needed. It is unlikely that all demands on school science curricula could be catered for, all stakeholders satisfied. However, previous analyses suggest that without an explicit identification and consideration of multiple aims and associated tensions successful curriculum reform is unlikely.

\section{Acknowledgements}

The authors thank Jim Donnelly for helpful comments on an earlier draft of this paper. The work reported here is one outcome from a larger study funded by the Economic and Social Research Council and the Gatsby Charitable Foundation, grant number RES-179-25-0004.

\section{References}

21st Century Science Project Team. (2003). 21st Century Science: A new flexible model for GCSE science. School Science Review, 85(310), 27-34.

Aikenhead, G. S. (2006). Science Education for Everyday Life. New York: Teachers' College Press.

Ball, S. J. (2008). The Education Debate. Bristol: The Policy Press.

Banner, I., Ryder, J., \& Donnelly, J. F. (2009). The Enactment and Impact of Science Curriculum Reform. . Paper presented at the European Science Education Research Association conference, Istanbul, Turkey.

Bell, J., \& Donnelly, J. (2007). Positioning applied science in schools: uncertainty, opportunity and risk in curriculum reform. Leeds: CSSME, University of Leeds.

Black, P., \& Atkin, J. M. (Eds.). (1996). Changing the subject: Innovations in science, mathematics and technology education. London: Routledge.

Blades, D. (1997). Procedures of power and curriculum change: Foucault and the quest for possibilities in science education. New York: Lang.

Bowe, R., Ball, S. J., \& Gold, A. (1992). Reforming Education and Changing Schools. London: Routledge. 
Burden, J., Campbell, P., Hunt, A., \& Millar, R. (2007, February). Evaluation of the Twenty First Century Science Pilot. Evaluation Report. Retrieved April, 2010, from http://www.21 stcenturyscience.org/rationale/pilotevaluation, 1493,NA.html

DeBoer, G. E. (2000). Scientific literacy: another look at its historical and contemporary meanings and its relationship to science. Journal of Research in Science Teaching, 37(6), 582-601.

DfES. (2005). 14-19 Education and Skills. London: HMSO.

DfES/QCA. (2004). Science: The National Curriculum for England. London: DfES/QCA.

Donnelly, J. (2005). Reforming science in the school curriculum: a critical analysis. Oxford Review of Education, 31(2), 293-309.

Donnelly, J., \& Jenkins, E. (2001). Science education: policy, professionalism and change. London: Sage.

Eijkelhof, H. M. C., \& Kapteijn, M. (2000). ANW: A new course on public understanding of science for senior general secondary education in the Netherlands. In R. T. Cross \& P. J. Fensham (Eds.), Science and the Citizen (pp. 189-199). Fitzroy, Victoria, Australia: Arena.

Elmore, R., \& Sykes, G. (1992). Curriculum Policy. In P. W. Anderson (Ed.), Handbook of Research on Curriculum. New York: Macmillan.

Fensham, P. (1988). Familiar but different: Some dilemmas and new directions in science education. In P. Fensham (Ed.), Development and Dilemmas in Science Education (pp. 1-26). London: The Falmer Press.

Fensham, P. (2009). The link between policy and practice in science education: The role of research. Science Education, 93(6), 1076-1095.

Gaskell, J. (2003). Perspective and possibilities in the politics of science curriculum. In R. Cross (Ed.), A vision for science education : responding to the work of Peter Fensham. London; New York: RoutledgeFalmer.

Gorard, S., \& See, B. H. (2009). The impact of socio-economic status on participation and attainment in science. Studies in Science Education, 45(1), 93-129.

H.M. Treasury, Department of Trade, \& Industry \& Department for Education and Skills. (2004). Science and innovation framework 2004-2014. London: HMSO.

Hill, M., \& Hupe, P. (2002). Implementing Public Policy. An Introduction to the Study of Operational Governance (second ed.). London: SAGE.

Hollins, M. (2001). Keeping school science in step with the changing world of the 21 st century: A curriculum development project by QCA. Education in Science, 194, 22-23.

House of Lords Science \& Technology Select Committee. (2006). Science Teaching in Schools. Retrieved November, 2009, from http://www.publications.parliament.uk/pa/ld200506/ldselect/ldsctech/257/257. $\underline{\mathrm{pdf}}$

House of Lords Science \& Technology Select Committee. (2007). Science Teaching in Schools: Follow-up Report.

House of Lords Science and Technology Select Committee. (2007). Science Teaching in Schools: Follow-up Report. Retrieved April, 2010, from http://www.publications.parliament.uk/pa/ld200607/ldselect/ldsctech/167/167. pdf 
Kahle, J. B. (2007). Systemic reform: Research, vision, and politics. In S. Abell \& N. G. Lederman (Eds.), Handbook of research on science education (pp. 911942). Mahwah, NJ: Erlbaum.

Kirk, D., \& MacDonald, D. (2001). Teacher voice and ownership of curriculum change. Journal of Curriculum Studies, 33(5), 551-567.

Kogan, M. (1975). Educational policy-making: A study of interest groups and parliament. London: George Allen and Unwin.

Laugksch, R. C. (2000). Scientific literacy: a conceptual overview. Science Education, 84(1), 71-94.

Leach, J. (2002). Teachers' views on the future of the secondary science curriculum. School Science Review, 83(204), 43-50.

Levinson, R., \& Turner, S. (2001). Valuable lessons: Engaging with the social context of science in schools: Wellcome Trust.

Millar, R. (2006). Twenty First Century Science: Insights from the design and implementation of a scientific literacy approach in school science. International Journal of Science Education, $28(13), 1499$ - 1521.

Millar, R., \& Osborne, J. (1998). Beyond 2000: Science education for the future. Retrieved April, 2010, from

http://www.kcl.ac.uk/content/1/c6/01/32/03/b2000.pdf

OCR. (2009). GCSE Twenty First Century Science Suite. Retrieved April, 2010, from http://www.ocr.org.uk/qualifications/type/gcse/tfcs/index.html

Osborne, J., \& Ratcliffe, M. (2002). Developing effective methods of assessing ideas and evidence. School Science Review, 83(305), 113-123.

Pring, R., Hayward, G., Hodgson, A., Johnson, J., Keep, E., Oancea, A., et al. (2009). Education for All: The Future of Education and Training for 14-19 year olds. London \& New York: Routledge.

QCA. (2005a). Evaluation and analysis of the 21st Century science pilot GCSEs. London: QCA.

QCA. (2005b). Science. Changes to the Curriculum from 2006 for Key Stage 4 [Electronic Version]. Retrieved April 2010 from https://orderline.qcda.gov.uk/gempdf/1847210686.pdf.

QCA. (2006). Written evidence from QCA to the House of Lords Science and Technology Select Committee 'Science Teaching in Schools Report'. Retrieved April 2010, from http://www.publications.parliament.uk/pa/ld200506/ldselect/ldsctech/257/257 we29.htm

QCA. (2007). The new secondary curriculum: What has changed and why. [Electronic Version]. Retrieved April 2010 from http://curriculum.qcda.gov.uk/uploads/overview doc tcm8-1839.pdf.

Reiss, M. (2007). What should be the aim(s) of school science education? In D. Corrigan, J. Dillon \& R. Gunstone (Eds.), The Re-emergence of Values in Science Education (pp. 13-28). Rotterdam/Taipei: Sense Publishers.

Roberts, D. A. (1988). What counts as science education? In P. Fensham (Ed.), Development and Dilemmas in Science Education (pp. 27-54). London: Falmer Press.

Roberts, D. A. (2007). Scientific literacy/science literacy. In S. K. Abell \& N. G. Lederman (Eds.), Handbook of Research on Science Education. Mahwah, NJ: Lawrence Erlbaum Associates.

Rudolph, J. L. (2005). Inquiry, instrumentalism, and the public understanding of science. Science Education, 89(5), 803-821. 
Solomon, J. (1993). Teaching Science, Technology and Society (STS). Buckingham: Open University Press.

The Nuffield Foundation. Retrieved February, 2009, from http://www.nuffieldfoundation.org/go/aboutus/page 139.html

The Royal Society. (2008). Science and Mathematics Education, 14-19: A 'state of the nation' report on participation and attainment of 14-19 year olds in science and mathematics in the UK, 1996-2007. London: The Royal Society.

Tomlinson, M. (2004). 14-19 Curriculum and Qualifications Reform: Final Report of the Working Group on 14-19 Reform [Electronic Version]. Retrieved April 2010 from http://www.desf.gov.uk/14-19/documents/Final\%20Report.pdf.

University of York/Nuffield Foundation. (2009). Twenty First Century Science. Retrieved April, 2010, from http://www.21stcenturyscience.org/home/

van den Akker, J. (1998). The science curriculum: between ideals and outcomes. In B. J. Fraser \& K. G. Tobin (Eds.), International handbook of science education (pp. 421-447). Dordrecht: Kluwer.

Wei, B., \& Thomas, G. (2005). Rationale and Approaches for Embedding Scientific Literacy into the New Junior Secondary School Chemistry Curriculum in the People's Republic of China. International Journal of Science Education, 27(12), 1477-1493.

Witz, K. G., \& Lee, H. (2009). Science as an ideal: teachers' orientations to science and science education reform. Journal of Curriculum Studies, 41(3), 409 431 . 
Qualifications and Curriculum Authority (QCA) curriculum projects commissioned

Development of Twenty First Century Science courses begins

2002

Piloting of Twenty First Century Science courses begins in

September 2003 schools

QCA publishes the revised 'programme of study' for science to be followed from September 2006

Government publishes ten-year Science and Innovation Investment Framework (SIIF)

Tomlinson report on 14-19 Reform published

October 2004

Government publishes '14-19 Education and Skills' White

February 2005 Paper

QCA publishes revised 'criteria for science'. These are used by

Early 2005 awarding bodies to generate science 'specifications' and associated assessment materials.

Publication of small-scale initial evaluations of Twenty First 2005 Century Science pilot

Publication of extended evaluations of Twenty First Century 2006 Science pilot

Teaching of the new science courses begins in all publically September 2006 funded schools in England

Table 1 A chronology of key events leading to the 2006 science curriculum reform in England 
Multiple aims in the development of curriculum reform

Key changes to the

Immediate aims

Longer term aims science curriculum

Increase student interest in their science education

Teaching about the nature of science and socioscientific issues

Providing flexibility to meet the needs of students
Improve student attainment as measured through external examinations
Support students in engaging effectively with science-related issues as citizens

Increase post-compulsory participation in science education

Ensure adequate supply of scientists/engineers

Increase the employability of students

Improve social mobility and inclusion

Table 2 Aims associated with the 2006 reform 
Multiple aims in the development of curriculum reform

Figure 1 A conceptual framework for examining policy reform (Bowe, Ball and CONTEXT OF POLICY TEXT PRODUCTION Gold, 1992) 
Multiple aims in the development of curriculum reform

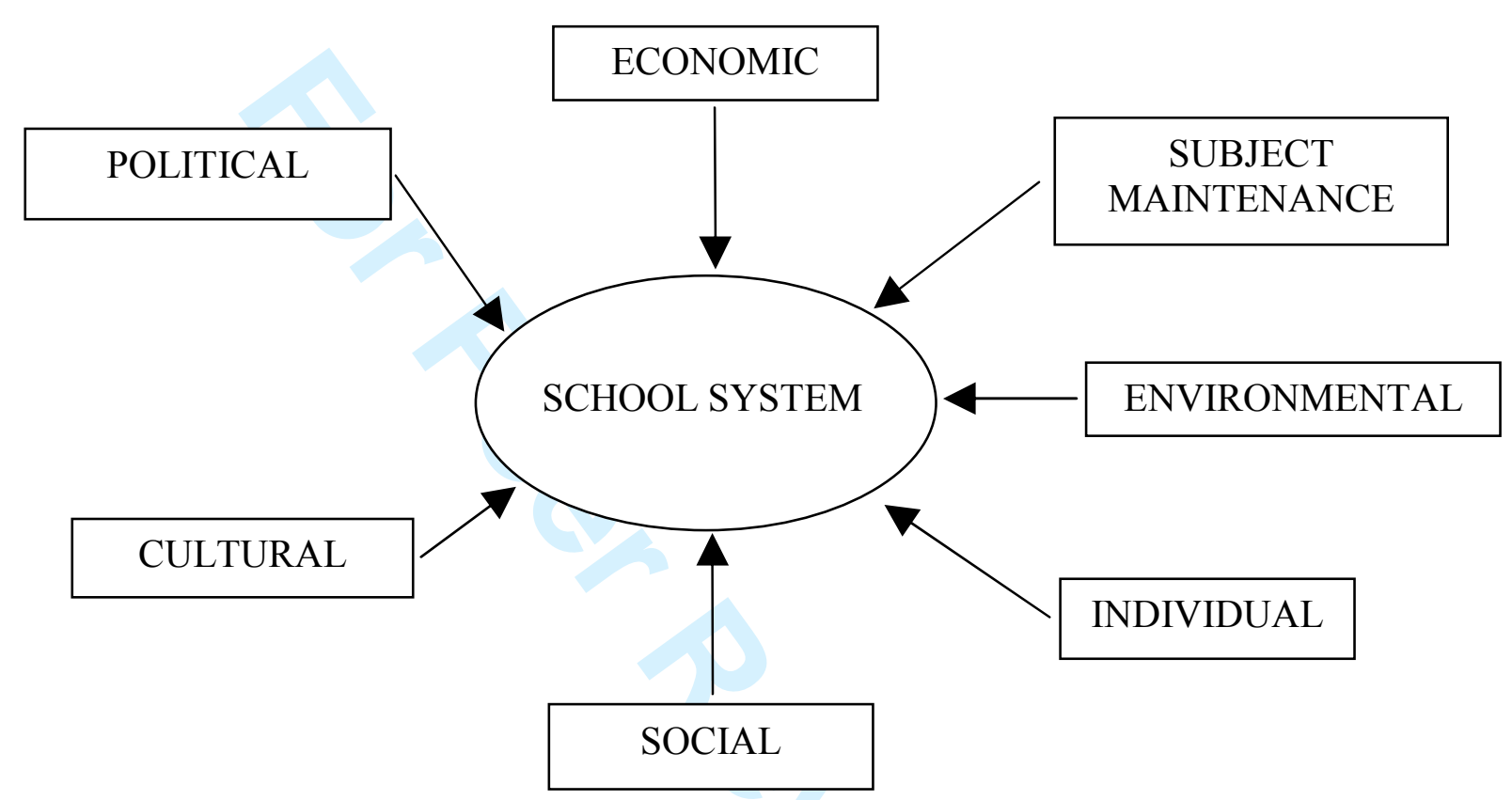

Figure 2 Demands on the school science curriculum (Fensham, 1988, 2009) 